\title{
COOPERATIVES' PROACTIVE SOCIAL RESPONSIBILITY IN CRISIS TIME: HOW TO BEHAVE?
}

\author{
POR \\ Cristina ARAGÓN AMONARRIZ ${ }^{1}$, \\ Cristina ITURRIOZ LANDART ${ }^{2}$ y \\ Lorea NARVAIZA CANTIN ${ }^{3}$
}

\section{RESUMEN}

La Responsabilidad Social Proactiva (RSP) juega un papel relevante en la construcción de la ventaja competitiva y en el éxito organizativo de las cooperativas, organizaciones basadas en principios cooperativos. El desarrollo de la RSP es especialmente complicado en los períodos de recesión. Este artículo examina cómo impactan las crisis económicas en las cooperativas a distintos niveles y pretende identificar cómo la RSP puede recuperarse. Para ahondar en el comportamiento organizativo, se ha empleado el enfoque de estudio de caso aplicado a tres cooperativas industriales situadas en el País Vasco (España).

El artículo identifica tres fuentes de barreras de la RSP en el contexto de las cooperativas y propone dos condiciones para el desarrollo de la RSP. La originalidad del artículo radica en que amplía la investigación en la responsabilidad de las cooperativas durante los períodos de crisis, examina la "caja negra" de las cooperativas para detectar problemas que dañan su RSP y propone las palancas de RSP de las cooperativas, palancas que pueden ser trasladadas a otros contextos organizativos.

Palabras clave: Responsabilidad Social Proactiva, recesión económica, economía social, estudio de caso, España.

Claves Econlit: D22, J54, L29, M14.

${ }^{1}$ Department of Strategy and Information Systems - Deusto Business School - University of Deusto, Mundaiz,
50, 20012 San Sebastián, Phone: 943297275, cristina.aragon@ deusto.es.
${ }^{2}$ Department of Strategy and Information Systems - Deusto Business School - University of Deusto, Mundaiz,
50, 20012 San Sebastián, Phone: 943326600, cristina.iturrioz@ deusto.es.
${ }^{3}$ Department of Marketing - Deusto Business School - University of Deusto, Mundaiz, 50, 20012 San
Sebastián, Phone: 943326298 , lorea.narvaiza@ @eusto.es. REVESCO No 123 - Primer Cuatrimestre 2017 - ISSN: 1885-8031 - www.ucm.es/info/revesco

http://dx.doi.org/10.5209/REVE.53252

Fecha de recepción: 12/03/2015

Fecha de aceptación: 18/07/2016 


\section{ABSTRACT}

Proactive Social Responsibility (PSR) plays a relevant role building competitive advantage and supporting organizational success in cooperatives. It is particularly desirable and challenging in recession periods. This paper studies how economic crisis impacts in different levels of cooperatives, and it aims to identify how PSR can be restored. In order to explore the organizational behaviour, the case study approach was selected to analyse three manufacturing cooperatives located in the Basque Country (Spain).

The paper identifies three sources of hinders of PSR in cooperative context and it proposes two conditions to develop PSR. The originality of the paper relies on pushing the research of the organizations' responsibility face to the crisis periods, diving into the cooperatives black box to catch the problems hindering their PSR, and proposing PSR leverages in cooperatives.

Keywords: Proactive social responsibility, economic downturn, social economy, case study, Spain.

\section{INTRODUCTION}

Sustainable development is supported by three factors (economic growth and prosperity, social cohesion and equality, and environmental integrity and protection) that are threatened by the current crisis. The financial crisis, starting in 2007 in US because of the liquidity shortfall in the banking system (Taylor \& Williams, 2009) impacted European market in 2008 (European Commission 2009; Aizenman, Chinna \& Ito, 2010). The effects of financial downturn, such as stock indexes fall, financial institutions collapse, higher unemployment, poverty, etc. (Adamu, 2009; Giannarakis \& Theotokas, 2011; Wim, 2009), are being relevant. As a result, the role of business in the current context becomes one of the main issues in the centre of the economic debate and it points out the social responsibility (SR) as a paradigm of modern business in the global economic crisis (Hristache, Paicu \& Ismail, 2013; Krauss, Rūtelionè \& Piligrimienè, 2010; Fernandez-Feijoo, 2009).

Following different authors, cooperative firms contribute to the economic, social and environmental sustainable development, expanding SR as a development mean (Palomo \& Valor, 2004; Belhouari, Buendía, Lapointe \& Tremblay, 2005; Ceballo, 2005; Vargas \& Vaca, 2005; Bel \& Marin, 2008; Puentes \& Velasco, 2009). However, SR is not only the 
consequence of the intrinsic nature of cooperative success but also the reason of cooperative competitive advantage (Server \& Capo, 2009). Additionally and in the particular context of economic crisis, organizations are forced to foster the interest for creating win-win situations by intensifying relations with customers, employees and the community in contrast to relying exclusively on abstract market relations (Krauss et al., 2010) and to strategically align organization's and stakeholders' interests. In fact, Arevalo and Aravind (2010) have observed that the firms that develop proactive efforts at implementing CSR increase their ability to cope with crises.

In this context, and drawing on the long-established 'reaction-defenceaccommodation-proaction' typology (Carroll 1979; Wartick and Cochran 1985; Wilson 1975), cooperatives are expected to base on their roots and develop a proactive social responsibility (PSR), in other words, to manage social responsibility issues as a competitive priority (Carroll 1979; Du et al. 2007; Groza et al. 2011; Wilson 1975) from which a competitive advantage can be derived (Benn et al. 2006; Berry and Rondinelli 1998; Klassen and Whybark 1999; Sharma and Vredenburg1998; Torugsa, O’Donohue and Hecker, 2012). In this sense, this is a suitable field to evidence how economic crisis can impact cooperative principles and to identify how PSR can be developed.

Therefore, our aim in this paper is to evaluate how economic crisis impacts the SR foundations and how PSR remains and can be supported. In order to reach this purpose, we use the case study methodology. In particular, we analyse three manufacturing cooperatives located in Gipuzkoa a territory in the Basque Country (Spain), where there is a high concentration of cooperative societies (Itçaina, 2002). The paper contributes to the debate in three ways. First, it pushes the research of the organizations' SR face to the crisis periods; second, it dives into the cooperatives black box to catch the problems hindering their SR; and finally, it enlarges the SR literature proposing SR leverages in cooperatives.

The following section analyses the relationship between SR and the current crisis. In Section III, the literature review presents PSR in crisis time as an appropriate SR approach in the cooperatives context. Section IV presents the problems to develop PSR in this context. In Section V, we try to identify these problems in three different case studies alongside with the conditions to overcome these problems. The sixth section concludes. 


\section{ECONOMIC CRISIS AND SR}

The prevailing economic crisis shapes the perception of companies and the general mood is rather pessimistic (Krauss et al., 2010). Firm's survival is threatened and, in this critical context, the economic purposes can dominate the firm behaviour in spite of the social or environmental care. The SR implementation costs at short-term can avoid appreciate the widely recognised benefits that SR generates in the long-term (Jenkins, 2006). In this sense, some companies neglect stakeholders' demands in crises periods (Kolk \& Pinkse, 2006); other, however, are socially responsible. These are probably the reasons for the lack of consistency of the literature linking economic crisis and SR.

Njoroge (2009) analyses how the current economic crisis affects multinational companies operating in Kenya, in particular in social projects and labour standards. Data for the empirical analysis is obtained from a telephone interview survey and analysis of Covalence database. As a result, the paper concludes that the economic downturn has minimal effect on labour standards, while there is an adverse effect on funding social projects.

Focused in the Spanish financial industry, Ruiz, De los Rios \& Tirado (2009) analyse how the financial institutions respond to the financial downturn from the point of view of Corporate Social Responsibility (CSR). In order to reach this purpose, they study the relationship between these organizations and their stakeholders. The information needed has been obtained from a survey sent to a set of CSR managers at some financial institutions. The results show the evolution undergone in terms of the procedures to be followed to incorporate the expectations of stakeholders in the management of CSR. However, the crisis is not considered a threat for CSR management but a strategic tool to overcome the current situation. In this sense, these authors consider this crisis period as a maturity stage of CSR.

Karaibrahimoglu (2010) investigates CSR performance in the pre-financial 2007, and in 2008, when crisis started in USA market. A hundred of companies are randomly selected from Fortune 500 database and their CSR performance is evaluated with twenty nine indicators obtained from annual non-financial reports. The stakeholder approach is adopted and five stakeholders are studied: employee, consumer, government, supplier and society. Results show that companies decrease CSR projects because of a financial downturn. CSR projects reduce more in the USA than in Europe and other countries. 
In the context of the companies that implement Global Report Initiatives (GRI), Giannarakis \& Theotokas (2011) aim to evaluate the effect of economic crisis in CSR. The empirical analysis was carried by 112 organizations from 2007 to 2010 . Results indicate that CSR performance has increased during the current crisis except for the 2009-2010 period. Thus, the companies try to regain the lost trust in businesses.

Table 1. Empirically tested relationship between current crisis, SR and cooperatives in academic research

\begin{tabular}{|c|c|c|c|}
\hline Authors & Conclusions & Period & Crisis impact in CSR \\
\hline Njoroge (2009) & $\begin{array}{l}\text { Adverse effect on funding social } \\
\text { projects. }\end{array}$ & & Negative \\
\hline $\begin{array}{l}\text { Ruiz et } \quad \text { al. } \\
(2009)\end{array}$ & $\begin{array}{l}\text { Undergone in terms of the } \\
\text { procedures to be followed to } \\
\text { incorporate the expectations of } \\
\text { stakeholders in the management } \\
\text { of CSR. }\end{array}$ & $2005-2008$ & Negative \\
\hline $\begin{array}{l}\text { Karaibrahimoglu } \\
\text { (2010) }\end{array}$ & Decrease CSR projects & $2007-2008$ & Negative \\
\hline $\begin{array}{l}\text { Giannarakis and } \\
\text { Theotokas } \\
\text { (2011) }\end{array}$ & $\begin{array}{l}\text { CSR performance has increased } \\
\text { during the current crisis except } \\
\text { for the } 2009-2010 \text { period. }\end{array}$ & $2007-2010$ & Positive \\
\hline
\end{tabular}

Source: Own elaboration.

The diverse understanding of the SR term, the different periods or geographical areas considered, the sample limitations, can be at the root of the divergent conclusions. However, other than non-methodological reasons can explain the diverse results achieved. The impact of crisis in SR can also depend on the firm attitude face to SR, which can be considered both, a threat for companies' survival because of the additional financial cost for the social initiatives, and an opportunity if it can be employed as a tool for helping firms to overcome the consequences of the crisis.

Therefore, is SR an option for firms in crisis period? A paper, written by Hristache et al. (2013), considers CSR and its role as an alternative identity model for the post-crisis economy. In particular, what corporate responsible company gives to society, it is expected to be received as a 'reward' coming from the society where it operates, increasing its own revenue. Moreover, these authors state that the aimed objectives of the 'healthy' modern business are social ethics, economic efficiency and environmental protection. Therefore, the $\mathrm{SR}$ as a paradigm of modern business is necessary in the current global economic crisis. 
In this sense, it has been proved that SR can have a protector effect in crises periods, almost for large companies (Arevalo \& Aravind, 2010). These authors have found that companies that integrate United Nations Global Compact (UNGC) principles with less conformity will be more touched by the financial downturn than companies that adopt a proactive policy concerning UNGC; specifically, "if an organization's CSR efforts are integrated well into the organization's fabric, then it is more likely that these efforts would be affected more when an economic crisis strikes" (Arevalo \& Aravind, 2010, p. 415). In this sense, Manubens (2009) and Krauss et al. (2010) claim the need of a strategic SR in order to overcome the current crisis. CSR is understood 'not as an additional burden, to be skipped in times of crisis, but a consistent and sustainable, long-term strategy, with the main resources of small and medium enterprises (SMEs), well qualified and motivated employees, good customer and community relations and a generally responsible and ethical business conduct at its centre' (Krauss et al., 2010: p. 640). Miras et al. (2014) show that large Spanish companies continue to carry out SR actions despite the effects of the crisis on their financial health, and underline the relevant influence of shareholders, more influential than managers in these strategic decisions.

Ducassy (2013) has studied other perspective of the relationship between SR and economic crisis, analysing if corporate social performance act as an insurance-like protection during periods of uncertainty. Findings show that there is some link since a positive relationship during the beginning of the crisis, but after a while no significant connection is found.

In conclusion, it seems the more a company has invested, or the more it has integrated CSR into its DNA, the stronger the impacts on its CSR performance. On the contrary, organizations without such integrated CSR levels or matured stages in CSR might not be reporting the same impacts as those with higher CSR integration.

\section{COOPERATIVES AND SR}

According to the International Cooperative Aliance ${ }^{4}$ a co-operative is 'an autonomous association of persons united voluntarily to meet their common economic, social, and cultural needs and aspirations through a jointly owned and democratically controlled enterprise'. As cooperative development is based on their context, people and participative management

\footnotetext{
${ }^{4}$ http://www.cdi.coop/icaprinciples.html.
} 
engagement, they represent the SR model (Castro, 2006). SR is not only an intrinsic element of cooperative societies, but it has a relevant role building competitive advantage and supporting organizational success (Fombrun \& Shanley, 1990, Marín \& Rubio, 2008; Greening \& Turban, 2000). Cooperative societies as social organizations have to invest their own financial resources and capabilities in the social strategy display (Barrera, 2007), boosting their reputation (Wanous, 1992). Therefore, they have a better strategic position due to their higher SR (Collado, 2006). The foundations of their socially responsible behaviour are rooted in their specific cooperative principles. Due to these principles, cooperatives are expected to be responsible towards their members and the society in general and, at the same time, economically viable (Mozas, Puentes \& Bernal, 2010). Following Arcas and Briones (2009), we consider five out of the seven cooperative principles, those that better link with SR.

Table 2. Cooperative principles and SR parallelism

\begin{tabular}{|l|l|}
\hline Cooperative principle & SR \\
\hline Voluntary and Open Membership & Integration \\
\hline Democratic Member Control & Participation \\
\hline Education, Training and Information & Transparency and extension \\
\hline Co-operation among Cooperatives & Integration \\
\hline Concern of Community & Sustainability \\
\hline
\end{tabular}

Source: Adapted from Arcas and Briones (2009)

The conceptual link between SR and cooperatives seemed to be evident, and the first empirical studies focused in looking for the accurate measurement of social efficiency (Peixe \& Protil, 2007) and of social responsible behaviour (Server \& Villalonga, 2007) in this organizational context. Both researches relate economic measurement and the use of the Fund for Education and Promotion as indicators allowing capture the social issues of these organizations.

Empirical studies about SR in the cooperative context show how SR was developed. In 2009, two papers analysed the fulfilment of the SR principles by Spanish social economy entities (Arcas \& Briones, 2009; Perez, Esteban \& Gargallo, 2009). Although these organizations deployed SR behaviours, some differences had been identified among the SR implementation, so the heterogeneity in the SR behaviours in these organizations was proved.

In the same sense, trying to capture the SR implementation, Bouchon, Mihcard, Plasse \& Paranque (2012) analysed French Scop. In particular, they studied how SR was developed 
in the current business activity, considering the interest of all the stakeholders. They concluded that the Scop workers seemed to be autonomous and to participate to relevant orientations of the organization, realising their real collective responsibility and that the social dialogue was a Scop principle and therefore, it was easier to include other stakeholders in the decision process.

A more focused analysis between cooperative members' loyalty and SR was developed by Cherubim \& Moura (2012) in the Brazilian cooperative context, finding no significant effect between SR and member's loyalty.

Table 3. Empirical studies about CSR in cooperatives $(2007-2013)^{5}$

\begin{tabular}{|c|c|c|}
\hline Authors & Purpose & Results \\
\hline $\begin{array}{l}\text { Cherubim and } \\
\text { Moura (2012) }\end{array}$ & 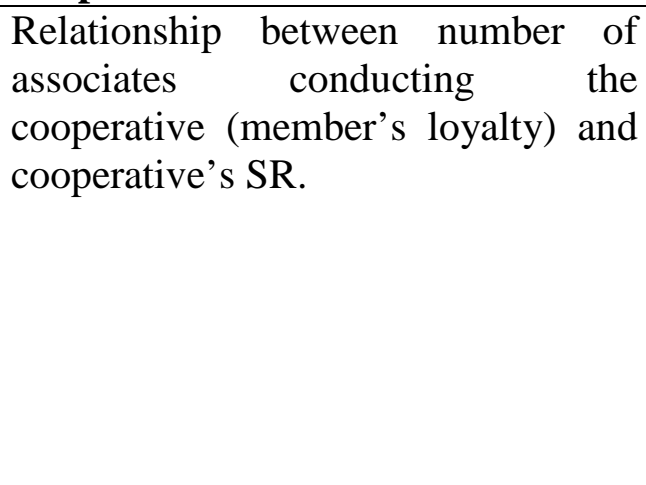 & $\begin{array}{l}\text { Special purpose reserves employ for } \\
\text { technical, educational and social } \\
\text { assistance programs and spending on } \\
\text { education and the environment have no } \\
\text { significant effect on the loyalty of the } \\
\text { cooperative's members. } \\
\text { The members' loyalty increases if the } \\
\text { cooperative has a greater capacity to } \\
\text { provide services and generate higher } \\
\text { returns for them. }\end{array}$ \\
\hline $\begin{array}{l}\text { Bouchon et } \\
\text { al. }(2012)\end{array}$ & $\begin{array}{l}\text { Analyses how SR is developed in the } \\
\text { current business activity, besides the } \\
\text { government, considering the interest } \\
\text { of all the stakeholders. }\end{array}$ & $\begin{array}{l}\text { The Scop worker seems to be autonomous } \\
\text { and to participate in relevant orientations } \\
\text { of the organization, realising his/her real } \\
\text { collective responsibility. His individual } \\
\text { and collective interests are aligned by the } \\
\text { auto regulation and the initiation system. } \\
\text { The social dialogue is a Scop principle } \\
\text { and therefore, is easier to include other } \\
\text { stakeholders in the decision process. }\end{array}$ \\
\hline $\begin{array}{l}\text { Perez et al. } \\
(2009)\end{array}$ & $\begin{array}{l}\text { Relationship between the } \\
\text { engagement in economic and social } \\
\text { issues and the level of fulfilment of } \\
\text { these issues by the cooperatives. }\end{array}$ & $\begin{array}{l}\text { The results highlight the different results } \\
\text { obtained according to the form of } \\
\text { participation and the groups of interest } \\
\text { involved. }\end{array}$ \\
\hline $\begin{array}{l}\text { Arcas and } \\
\text { Briones } \\
(2009) \\
\end{array}$ & $\begin{array}{l}\text { To what extent cooperatives are } \\
\text { adopting behaviours that are features } \\
\text { of the CRS, if the degree of adoption }\end{array}$ & $\begin{array}{l}\text { The result of these authors proves that the } \\
\text { analysed Social Economy Entities, } \\
\text { cooperative organizations and labour }\end{array}$ \\
\hline
\end{tabular}

\footnotetext{
${ }^{5}$ Additionally, more focused studies have been carried out related with accountancy and SR communication. Mozas et al. (2010) show that even if SR is developed in cooperatives, in Spanish agriculture cooperatives it is not communicated to the stakeholders though web pages. The lack of communication is proved also in the Canadian Financial Service Cooperatives (Rizkallah \& Buendia, 2011). However, in the case of French agricultural cooperatives, Taddei and Delecolle (2012) have found that cooperatives enhance internal communication. In fact, they understand the various provisions involved in CSR and provide information, training, and support for their members' projects (very small-scale farms), which more broadly concern issues arising from their activities.
} 


\begin{tabular}{|l|l|l|}
\hline & $\begin{array}{l}\text { differs between the cooperatives and } \\
\text { the labour societies and if this } \\
\text { adoption is affected by the values } \\
\text { shared by these organizations. }\end{array}$ & $\begin{array}{l}\text { societies, fulfil their principles and } \\
\text { develop SR behaviours. }\end{array}$ \\
\hline $\begin{array}{l}\text { Server and } \\
\text { Villalonga } \\
(2007)\end{array}$ & $\begin{array}{l}\text { Relationship between the socially } \\
\text { responsible behaviour and what is } \\
\text { stated as the guiding principles on } \\
\text { which Cooperatives base their } \\
\text { behaviour. }\end{array}$ & $\begin{array}{l}\text { Credit cooperatives tend to socially } \\
\text { responsible behaviour and admit the role } \\
\text { of the Fund for Education and Promotion } \\
\text { as a basic element for the SR evaluation. }\end{array}$ \\
\hline $\begin{array}{l}\text { Peixe and } \\
\text { Protil (2007) }\end{array}$ & $\begin{array}{l}\text { Analyses the indexes used to } \\
\text { measure social efficiency in } \\
\text { cooperatives. }\end{array}$ & $\begin{array}{l}\text { The indexes used to measure social } \\
\text { efficiency in cooperatives are directly } \\
\text { influenced by strictly economic indexes. }\end{array}$ \\
\hline
\end{tabular}

Source: Own elaboration

Looking at the literature, the research developed points out the link between SR and cooperative principles (Castro, 2006; Fombrun \& Shanley, 1990; Marín \& Rubio, 2008; Greening \& Turban, 2000; Server \& Capó, 2009). The SR complete integration in business activity and process alongside with the vision of sustainability is one of the viable solutions to solve problems facing the contemporary crisis (Hristache et al. 2013). In the cooperative context, this integration is based in the application of cooperative principles and the development of PSR.

PSR is considered 'as responsible business strategies that support the three principles of sustainable development -economic growth and prosperity, social cohesion and equity, and environmental integrity and protection- at a level over and above that required to comply with government regulations' (Torugsa et al., 2012). It is needed to overcome the vulnerability of the firm that face a declining market, and become the SR implementation's cost into an investment face to the emergent opportunities generated in the context. Otherwise, SR can be reduced or focused in operational fragmented issues, instead of consolidating strategic decisions. Therefore, we assume that PSR, a self-demanding attitude of SR, is a necessary asset in the current economy.

\section{COOPERATIVES' PSR IN CRISIS CONTEXT}

Although they are at the roots of cooperatives and drivers of PSR, cooperative principles are not always applied or even respected by cooperatives' stakeholders. In this sense, the role of the stakeholders in cooperative's governance, and in the power asymmetry (Van der Vegt, de Jong, Bunderson, and Molleman, 2010); and the configurations of the stakeholders' information structures influence on knowledge transfer (Lin, Geng and 
Whinston, 2005) and on shared vision (Torugsa et al., 2012) have been identified as relevant to PSR.

The intrinsic SR in cooperatives, as the result of the cooperatives' principles application, can be inexistent when the cooperative nature is just supposed, but not managed. The intrinsic SR in cooperatives can be deteriorated along the time, satisfying the minimum requirements asked by regulations. This lack of 'cooperativeness' is not a specific consequence of the economic crisis. However, the consequences of cooperative principles' fading are more evident in downturn due to the significant investment in resources required and the long term results associated to PSR (Eisenhardt \& Martin, 2000; Hart \& Ahuja, 1996; Russo \& Fouts, 1997; Torugsa et al., 2012). Three are the main fields where this worsening situation can be found.

First and following the Slack Resources Hypothesis, SR depends on the availability of financial resources. At the worker level, the individual situation of the different members of the cooperative is not homogeneous and the effect of the crisis is not similar. For instance, cooperative's partners reduce more their workday but less their salary than no-partners in crisis periods (Calderon \& Calderon, 2012). This asymmetric situation can weaken cooperative values, which are cannibalised by other values or particular interests. It usually happens when economic climate is deteriorated and organizational survival is unclear. In this sense, the more the organizations keep reaching solid and sustainable financial results, the more SR is viable. On the contrary, opportunistic behaviours are likely to appear.

Second, at the governance level, the disagreement between blue and white collar workers, in particular when managers are external professionals, hired by a manufacturing cooperative, and the Government Council is basically integrated by workers without management experience, creates an unbridgeable crack. The traditional lack of trust and the difficulties of communication existing between them are exacerbated when financial resources are scarce and work is reduced. If this situation lasts, the antagonism becomes permanent and the dialogue breaks off, making irreconcilable the relationship between these two business statements. If this disagreement is based on managerial non-knowledge of the Government Council members, the situation can be dangerous to the competitiveness and survival of the organization in the crisis context. 
Related with the previously mentioned problem, a third issue can be identified at the managerial level. Sometimes, social rights are preserved due not to a socially responsible attitude, but to the rejection to unpopular decisions. Agency theory is a useful theoretical framework to understand the relevance of the relationships and the balance of power between owners/governors and managers - principals and agents (Fama and Jensen 1983) in the design and implementation of PSR. This issue, not particular of a specific economic context, outstands in turn down situations. It is also possible that the economic pressures and the rude rivalry among competitors, frequent in financial crises, relegate social and environmental issues to the background of the managers' agenda. The Managerial Opportunism Hypothesis (Williamson, 1965) can be considered in this context where managers replace cooperative principles by economic or personal objectives. This opportunism hinders SR due to the influence of personal characteristics and values of leaders in SMEs' social responsibility (Longenecker, McKinney \& Moore, 1989; Vyakarnam, Bailey, Myers \& Burnett, 1997; Lepoutre \& Heene, 2006; Longenecker, Petty, Moore \& Palich, 2006; Preuss \& Perschke, 2010). 
Table 4. Cooperative's problems to develop PSR in crisis time

\begin{tabular}{|c|c|c|}
\hline Level & Origin & Problem \\
\hline $\begin{array}{l}\text { 1. Worker } \\
\text { level }\end{array}$ & $\begin{array}{l}\text { The individual situation of the } \\
\text { different members of the } \\
\text { cooperative is not homogeneous } \\
\text { and the effect of the crisis is not } \\
\text { similar on each other. }\end{array}$ & $\begin{array}{l}\text { Particular interests motivate the workers } \\
\text { position in the cooperative and } \\
\text { opportunistic behaviours appear, failing } \\
\text { the collective project's foundations. }\end{array}$ \\
\hline $\begin{array}{l}\text { 2. Governance } \\
\text { level }\end{array}$ & $\begin{array}{l}\text { The governance committees can } \\
\text { be integrated by blue and white } \\
\text { collar workers. The } \\
\text { disagreement between them } \\
\text { creates an unbridgeable crack, } \\
\text { more evident in crisis time due } \\
\text { to the need to select the } \\
\text { allocation of the scarce } \\
\text { resources. }\end{array}$ & $\begin{array}{l}\text { If this situation lasts, the antagonism } \\
\text { becomes permanent and the dialogue } \\
\text { breaks off, making irreconcilable the } \\
\text { relationship between these two business } \\
\text { statements and weakening the focus on } \\
\text { cooperative principles and therefore the } \\
\text { proactiveness of SR. }\end{array}$ \\
\hline $\begin{array}{l}\text { 3. Managerial } \\
\text { level }\end{array}$ & $\begin{array}{l}\text { Two cases are considered: } \\
\text { - Social rights are preserved } \\
\text { due not to a socially } \\
\text { responsible attitude, but to } \\
\text { the rejection to unpopular } \\
\text { decisions. This issue, not } \\
\text { particular of a specific } \\
\text { economic context, outstands } \\
\text { in downturn situations. } \\
\text { Economic pressures and the } \\
\text { rude rivalry among } \\
\text { competitors, frequent in } \\
\text { financial crises, relegate } \\
\text { social and environmental } \\
\text { issues to the background of } \\
\text { the managers' agenda. }\end{array}$ & $\begin{array}{l}\text { Each case have different consequences: } \\
\text { - Economic criteria are not considered } \\
\text { due to the unpopular decisions } \\
\text { required by this perspective. Social } \\
\text { issues are attended but cooperative's } \\
\text { competitiveness is damaged. } \\
\text { - Economic criteria prevail over other } \\
\text { judgment in the decision making } \\
\text { process, hurting cooperatives } \\
\text { principles and SR in cooperatives. }\end{array}$ \\
\hline
\end{tabular}

Source: Own elaboration

Face to these problems arising in crisis time, the relevant question is how organizations overcome these barriers particularly relevant in crisis periods and develop a PSR. In order to respond to this question, we monitored whether the three mentioned problems occur in three cooperatives and how they solve them, trying to identify which leverages operate in the cooperative's SR context in crisis periods.

\section{METHODOLOGY}

A case study explores 'a contemporary phenomenon in its real context, where the limits between the phenomenon and the context are not well defined, and in which multiple sources of evidence are used' (Yin, 1989). It is hence an ideal method for exploring the 
organizational reaction in crises context, which requires exploration in depth (Eisenhardt, 1989). The case study refers to three manufacturing cooperatives located in Gipuzkoa territory in the Basque Country in northern Spain. This territory is highly concentrated in cooperative societies and a large number of them belong to Mondragon Cooperación Cooperativa. According the World Cooperative Monitor, Mondragon is the 28th largest cooperative group in the world, and the largest in the Industry and Utility sector, which head office, is located in this region.

Table 5. Case study information

\begin{tabular}{|l|c|c|c|}
\hline & CASE A & CASE B & CASE C \\
\hline Age & $\begin{array}{c}1963 \text { (from the business } \\
\text { creation) }\end{array}$ & $\begin{array}{c}1986 \text { (previously it was a } \\
\text { society) }\end{array}$ & $\begin{array}{c}1982 \text { (previously it } \\
\text { was a society) }\end{array}$ \\
\hline $\begin{array}{l}\text { Employee } \\
\text { number }\end{array}$ & 110 & 43 & 42 \\
\hline $\begin{array}{l}\text { Cooperative } \\
\text { membership }\end{array}$ & $70(63 \%)$ & $35(80 \%)$ & $27(64 \%)$ \\
\hline Activity & $\begin{array}{c}\text { Camping, garden, terrace } \\
\text { and beach furniture }\end{array}$ & $\begin{array}{c}\text { Ovens, proofing } \\
\text { chambers, silos and } \\
\text { freezing chambers for } \\
\text { bakeries and pastries. }\end{array}$ & Kitchen furniture \\
\hline Location & Gipuzkoa, Spain & Gipuzkoa, Spain & Gipuzkoa, Spain \\
\hline Independent & No. It belongs to MCC & Yes & Yes \\
\hline Interviewed & $\begin{array}{c}\text { CEO } \\
\text { Cooperative member }\end{array}$ & $\begin{array}{c}\text { Cooperative's president } \\
\text { Cooperative member }\end{array}$ & $\begin{array}{c}\text { Financial Director } \\
\text { Cooperative member }\end{array}$ \\
\hline
\end{tabular}

Source: Own elaboration

Selection of these specific cooperatives for this study was guided by two main criteria. Firstly, the different PSR level of each one of the cooperatives, as has been expressed by the interviewed leader. Secondly, they share a set of similar characteristics (industry, almost thirty years old, medium-sized organizations, their employees are mainly partners and located in the same region) that make them comparable in terms of SR.

We gathered data from each company referring to a period of 3 years, 2011-2013. During this time, each cooperative has suffered differently the crisis impact. When members of an organization describe their identity, they make implicit claims about what they deem to be salient characteristics (Moshman, 1998). In order to avoid subjectivity, we devote particular attention to the actions that are described by managers.

Constructive validity of the case analysis was ensured by the use and triangulation of various sources of evidence and the contrasting of results with the key agent in each case 
(Yin, 1998). The chain of evidence was constructed from press items in the period 2011-2013, information in the cooperative webpage, and a detailed face-to-face interview with the leader of each cooperative (Table 6). Internal validity was ensured by the design of a dedicated framework, based on the relevant literature and on preliminary assumptions (Table 7).

Table 6. Description of the key informants and information sources

\begin{tabular}{|c|c|c|c|}
\hline $\begin{array}{l}\text { Name of } \\
\text { cooperative }\end{array}$ & Type of Source & Interviewee' Description & Description of the evidence \\
\hline A & $\begin{array}{l}\text { Semi-Structured interview } \\
\text { JC.S.: CEO with more than } \\
\text { three decades experience in } \\
\text { this top position in the } \\
\text { cooperative. }\end{array}$ & $\begin{array}{l}\text { Interview audio taped on the } 10 \\
\text { the May of } 2013 \text { in the firm } \\
\text { facilities }\end{array}$ & $\begin{array}{l}\text { Transcription of the } \\
\text { interview of } 2574 \text { words }\end{array}$ \\
\hline \multirow[t]{2}{*}{ B } & Semi-Structured interview & $\begin{array}{l}\text { I.G.: President of the } \\
\text { cooperative with more than } 14 \\
\text { years as member of the } \\
\text { cooperative }\end{array}$ & $\begin{array}{l}\text { Interview audio taped on the } \\
\text { 9th May of } 2013 \text { in the firm } \\
\text { facilities } \\
\text { Transcription of the } \\
\text { interview of } 2499 \text { words }\end{array}$ \\
\hline & Direct Observation & Visit to the facilities & $\begin{array}{l}\text { Approx. } 1 \text { hour visit to the } \\
\text { facilities on the } 9 \text { th of May } \\
\text { of } 2013\end{array}$ \\
\hline $\mathrm{C}$ & Semi-Structured interview & A.B.: Financial Director & $\begin{array}{l}\text { Interview audio taped on the } \\
25 \text { of April of } 2013 \\
\text { Transcription of the } \\
\text { interview of } 4737 \text { words }\end{array}$ \\
\hline \multirow[t]{2}{*}{ Mixed data } & \multicolumn{2}{|l|}{ Documental information } & $\begin{array}{l}\text { Cooperative Annual Reports } \\
\text { Different articles regarding } \\
\text { cooperatives } \\
\text { Other cooperative } \\
\text { interviewees }\end{array}$ \\
\hline & \multicolumn{2}{|c|}{ University and Business Collaboration } & $\begin{array}{l}\text { Development of a series of } \\
\text { ten case studies about the } \\
\text { cooperative experience for } \\
\text { teaching and researching } \\
\text { purposes. }\end{array}$ \\
\hline
\end{tabular}

Source: Own elaboration 
Table 7. Summary of the structure of the interviews: Main dimensions and key issues

\begin{tabular}{|c|c|}
\hline DIMENSIONS & KEY ISSUES \\
\hline Interviewee Description & $\begin{array}{ll}- & \text { Interviewee's Position in the cooperative } \\
\text { - } & \text { Interviewee's experience in the cooperative context. }\end{array}$ \\
\hline Unit of Analysis Description & - $\quad$ Unit characteristics: main activities, size, structure, goals, results \\
\hline $\begin{array}{l}\text { The cooperative model and the } \\
\text { influence during the crisis }\end{array}$ & $\begin{array}{ll}\text { - } & \text { The MCC Mission, Vision and strategic objectives } \\
\text { - } & \text { Evolution/Dynamic perspective: Key events or main stages } \\
\text { - } & \text { The cooperative model } \\
\text { - } & \text { Governance of the cooperative } \\
\text { - } & \text { How are decisions taken? }\end{array}$ \\
\hline $\begin{array}{l}\text { The cooperative principles and its } \\
\text { influence during the crisis }\end{array}$ & $\begin{array}{ll} & \text { The } 7 \text { cooperative principles } \\
\text { - } & \text { The influence of the cooperative principles during the crisis } \\
\text { - } & \text { Values in the cooperative }\end{array}$ \\
\hline $\begin{array}{l}\text { The social economic balance in the } \\
\text { cooperative }\end{array}$ & $\begin{array}{ll}\text { - } & \text { Evolution/Dynamic perspective: Key events or main stages } \\
\text { - } & \text { Priorities and reasons } \\
\text { - } & \text { Importance of economic and social issues and priorities }\end{array}$ \\
\hline $\begin{array}{l}\text { The cooperative and the } \\
\text { members/employees }\end{array}$ & $\begin{array}{ll}- & \text { How are they paid? } \\
\text { - } & \text { Differences between members and non-members? } \\
\text { - } \quad \text { Limits to non-members? }\end{array}$ \\
\hline $\begin{array}{l}\text { Cooperative and relationships to } \\
\text { other stakeholders }\end{array}$ & $\begin{array}{ll}- & \text { Main stakeholders } \\
\text { - } & \text { Advantages and disadvantages of being a cooperative towards the } \\
\text { stakeholders }\end{array}$ \\
\hline Cooperative and leadership & $\begin{array}{ll}\text { - } & \text { Concept of leadership. Difference with non-cooperative firms. } \\
\text { - } & \text { Role of formal and informal leaderships } \\
\text { - } & \text { Styles of leadership } \\
\text { - } & \text { How decisions are taken? Centralization/Decentralization }\end{array}$ \\
\hline Cooperative and networks & $\begin{array}{ll}- & \text { Part of group or network of cooperatives? } \\
\text { - } \quad \text { Part of other types of networks? } \\
\text { - } \quad \text { External consultants? }\end{array}$ \\
\hline Results achieved & $\begin{array}{ll}- & \text { Indicators used } \\
- & \text { Results obtained at the correspondent level } \\
- & \text { Results perceived at MCC level } \\
\text { - } & \text { Evolution/Dynamic perspective: Key events or main stages }\end{array}$ \\
\hline
\end{tabular}

Source: Own elaboration

Regarding the external validity, the case study research carries out analytical generalization in which particular findings are generalized into a broader theory (Yin, 2003). Nevertheless, we cannot transfer our findings, since in this exploratory study only three selected cases have been analysed. Our analytical framework was designed specifically to identify hinders and drivers fostering socially responsible behaviour in the context of its application and a larger scope of scenarios have to be considered in order to generalise the results. 


\section{RESULTS}

Case A is a cooperative launched in 1963 and belongs to MCC. It has been managed during the last thirty three years by an internal manager, who has believed in the cooperative principles and has successfully looked after their implementation (third problem).

Belonging to MCC supposes having formalised management processes and communication channels. However, in order to have a more direct relationship with workers, the CEO eliminated the Social Council. Therefore, the dialogue with workers is directly leaded by the CEO bimonthly in the General Assembly and the level of agreement about cooperative strategy and the purpose of the organization among board's members and workers (including Governing Council members) is high, around 70\% (second problem). Therefore, the five cooperative principles related with SR values are applied and shared by a high number of employees, limiting opportunistic behaviours appear, and that fails the collective project's foundations (first problem).

The first principle, about Open and Voluntary Membership, is fulfilled, even if no new investment proposals have happened. The principle related with Democratic Member Control is also assured, but with a specific characteristics in this case. 'The communication is abundant, a management committee is hold monthly, and an reporting meeting is held with the cooperative's General Assembly and I explain the cooperative's situation to the Governing Council once by two month.'[...] 'In our cooperative we have no Social Council in order to avoid intermediates and to preserve a direct communication between the cooperative direction and the workers'.

The third principle related with Education, Training and Information is also accomplished. 'We have regulations [in order to link the cooperative benefits to the workers' wages]. If people are conscious of this reward, it is an advantage. 'There is a high level of transparency and solidarity in the cooperative. This is important because all the decisions depend on the partners' opinion. As a result, if they are informed in prosper times they are thankful and in crises periods they are flexible'. [...] 'The communication is abundant in the cooperative, and the participation rate is very high: everyone knows that he can talk'

The fourth principle focused on Cooperation among Cooperatives is applied because case A belongs to a larger cooperative group and this cooperation is one of the principles imposed by the group. 'Solidarity among cooperatives also exists into the group. A part of the 
benefits is destined to the reconversion, therefore, some are keepers and others are givers. Besides, $7 \%$ of our partners come from other cooperatives. And the financial brand of the group assures that workers are moved from one cooperative to another if the first one shuts down.'

The last principle regards the Concern of Community. 'The first thing is the mission (economic) accomplishment, after that there is the social and the environmental issues.' 'At the end, we are responsible of the future of families and the personal welfare of people is linked with the economic stability. The responsibility as CEO is enormous'. 'We are very concern about environmental issues and we have got all the certifications in this field'. 'Environment, Ecodesign, and ISO... for us this issue is highly important because the context and the stakeholders are looking at us. You have to try to be an example for the others. Nowadays, it is a requirement to sell in the global market'.

As a result, the SR is embedded in the current activity of the cooperative. In this sense, face to the crisis, the cooperative is strategically proactive, as it keeps on looking at the market, monitoring rivals activity, and translating all they capture into the product in order to maintain or improve its competitiveness. 'It is important to listen to the customers. If you go to an exhibition and listen, you can come with lot of ideas. Innovation begins from the listening capacity and the capacity of understanding the market needs. In order to see if we are able to generate value in this field, we analyse the rivals and we prepare a briefing with the designers. The purpose is to generate value with our offer and to propose something more attractive than the competitors.'

Case B, is an independent cooperative since 1986. Before it was a corporation. Recently due to the turndown's impact in the organization, the cooperative is been oriented by a consultant group. As a result, a new organizational structure was established and the cooperative roots were reactivated. After a long period without working on the cooperative principles, the economic crisis stimulated a change and, alongside this year, the organization has been fostering cooperative principles in the organization.

The new project proposed by the consultant was accepted and approved by $95 \%$ of the General Assembly (first problem). It has been understood by almost all the organizational members as an opportunity to overcome the economic crisis. Consequently, the organizational structure was flattened and the CEO was replaced by a group of team leaders (third problem): 
'We were suffering a difficult situation, there was tension between us, salary reductions, we were losing the spirit of the cooperative, and the labour atmosphere was deteriorating. This group has changed us and they promote the cooperative spirit. We had a pyramidal model of company and now, we have a horizontal company, with team-works with their leaders and in this way, people is more involved. We needed fresh air.'

In this context, the communication among the members of the cooperative and the participation in the decision process is assured and the relation between governing and managing boards highly aligned around the cooperative's vision statement (second problem): 'To offer, to all the industries that can employ our know-how in the world, sure, reliable, and profitable machinery, that are able to produce customers completely satisficing final products.'

In this case, the four out of the five cooperative principles related with SR values are applied. In particular, the first principle, about Open and Voluntary Membership, is compiled as cooperative partners are able to leave the organization at any moment. While they belong to the cooperative, the second principle, related with Democratic Member Control, is also assured. 'Since January 2013, we have changed the business framework. [...] Now, we are equal and all of us are similar in the decision making process. Now our structure is horizontal and we are organised in working groups leaded by workers and where the team is strongly engaged'. [...] 'Now, we have not a CEO, but a general coordinator but he does not decide. Monthly, the team leaders meet and take decisions.'

The third principle related with Education, Training and Information is now formally developed. 'Now we are more aware about people commitment and we improve peoples' engagement. We are now a real cooperative, not as before. Now, we are implementing these [cooperative] values. These people have trained us and other group of companies and we can take advantage of the synergies that appear. There is always an experience of other company that is useful for us, we have learned a lot in the process.'

Even if the fourth principle, focused on Cooperation among Cooperatives, is not fulfilled, the cooperative's concern of community is developed 'The advisor has create a firm network to work in favour of the society. In my cooperative, I am the Society Commitment Responsible. The advisor group aims the firms to return to the society a part of what the 
society has received. For instance, in the environmental area, we plant trees in spring or we invest in ecological orchard business in order to create employment and fight joblessness'.

The communication among the members of the cooperative and the participation in the decision process is encouraged by a new strategic management. Following the President opinion, in this new climate, the proactivity is stimulated and the cooperative's purpose is now shared by three quarters of the workers. 'We have not gone forward, but now we have some plans for the future. We have to innovate. We have create a Product Innovation team to analyse and propose new products. We have collaborated with Gaitek and Ikerlan [technological centres]. Considering the large experience of one of our clients working with one of our products, we have improved an existent oven. [...] We are also proactive in looking for new markets, for instance, in Iran. Helped by another company we are trying to penetrate in this new territory'.

Finally, case $\mathrm{C}$ is an independent manufacturing cooperative created in 1982. Even if it is not a result of the economic crisis, the cooperative spirit has faded. However, the pressures generated by the crisis have showed that the relationship between the Management Board and Governing Council was difficult and the cooperative principles were put in a secondary place among the cooperative's criteria.

Regarding the alignment between cooperative's boards (second problem), the disagreements between the CEO, an external manager, and the Governing Council, leaded by workers, have derived in firing the manager (the third problem is not considered). Economic issues are prevalent, unbalancing SR and fragmenting the head of the cooperative. 'In 2011 we lived a horrible situation. In 2012 we have kept our sales level while others were losing market share. The industrial decline was relevant and our downsizing was smaller. It was not enough for one part of the Governing Council that has considered that the cooperative was losing money. And, even if the CEO was doing things right, he has been fired. The leadership in this case was in the hand of one of the workers not able to appreciate the work of the managers.'

In 2011, the market reduction required the cooperative's downsizing and the organization proposed to its partners voluntary to leave. Thereby, one third of the partners left the cooperative (first problem). The expectation of remaining partners about cooperatives performance has increased under a pressured atmosphere. 
In particular, the first principle, about Open and Voluntary Membership, has been applied. In 2011, the market reduction required the cooperative's downsizing and the organization proposed to its partners to leave. Thereby, one third of the partners left the cooperative. The remaining partners were more engaged with the cooperative and the Democratic Member Control was assured by an active Governing Council. 'Here the main board is the General Assembly, each partner is a vote, and in this board very different opinion and interests are gathered. The General Assembly, which designs the Governing Council, is quite strong. It is mostly integrated by workers and they are not always ready to make a long term analysis of the economic situation. As a result, in our cooperative, the CEO has been fired'. 'The Governing Council meets monthly and it reports to the assembly. It controls the cooperative's activity: financial statements, the annual plans,... are approved by it'.

Relating to the third principle, focused in Education, Training and Information, it is not completely fulfilled. 'The capacity of partners in General Assembly to criticize the management of the Management Board is very relevant. They have the information, but if they are not able to make a strategic analysis of the situation their level of power can hurt the firm's competitiveness'. 'The cooperative's federation proposes courses to the Governing Council about their rights and obligations, but they are not interested in this kind of courses.' In fact, the participation of workers is not direct. The Management Board takes the decisions and it is controlled by the Governing Council.' The fourth principle focused on Cooperation among Cooperatives, and the principle regarding the Concern of Community, are not applied in case $\mathrm{C}$.

As a result no vision statement has been formalised, and the purpose of the firm is not shared by its members and proactivity is not promoted in the cooperative. In particular, in term of proactiveness, 'we collaborate with technological centres when they propose us an innovative project, but we are not proactive'. 
Table 8. PSR problems and governance and management alignment around cooperative principles in the three case studies

\begin{tabular}{|c|c|c|c|}
\hline & CASE A & CASE B & CASE C \\
\hline $\begin{array}{l}\text { Problem 1. Opportunistic } \\
\text { behaviours } \\
\text { cooperative workers }\end{array}$ & No & No & Yes \\
\hline $\begin{array}{lr}\text { Problem 2. } & \begin{array}{r}\text { Irreconcilable } \\
\text { relationship }\end{array} \\
\text { boverning } & \text { Council and } \\
\text { Managerial Committee. }\end{array}$ & No & No & Yes \\
\hline $\begin{array}{l}\text { Problem 3. Managerial } \\
\text { balance among SR areas: } \\
\text { economic versus social and } \\
\text { environmental. }\end{array}$ & Balance & Recently balanced & $\begin{array}{l}\text { Unbalanced. Economic } \\
\text { priority }\end{array}$ \\
\hline $\begin{array}{l}\text { Leader promoting shared } \\
\text { cooperative principles } \\
\text { embedded in cooperative } \\
\text { activity }\end{array}$ & $\begin{array}{l}\text { Yes. The values are } \\
\text { shared by the main } \\
\text { cooperative members } \\
\text { as a result of a work } \\
\text { made more than } 30 \\
\text { years ago. } \\
\text { Cooperative principles } \\
\text { are applied in the } \\
\text { current activity. }\end{array}$ & $\begin{array}{l}\text { Yes. Since January } 2013 \text {, the } \\
\text { values are being } \\
\text { implemented with a high } \\
\text { level of consensus. } \\
\text { Cooperative principles are } \\
\text { applied in the current } \\
\text { activity. }\end{array}$ & $\begin{array}{l}\text { No. The cooperative } \\
\text { principles are not at the } \\
\text { basis of the decisions } \\
\text { in the cooperative. } \\
\text { Cooperative principles } \\
\text { are not totally applied. }\end{array}$ \\
\hline $\begin{array}{lr}\text { Alignment } & \text { between } \\
\text { management } & \text { and } \\
\text { governance } & \text { around } \\
\text { cooperative's mission }\end{array}$ & $\begin{array}{ll}\text { Aligned } & \text { after } \quad \text { a } \\
\text { leadership } & \text { of thirty } \\
\text { years. } & \end{array}$ & $\begin{array}{l}\text { New president has facilitate } \\
\text { a recent alignment, helped } \\
\text { by the advisor of a } \\
\text { consultant }\end{array}$ & $\begin{array}{lr}\text { Not aligned. } & \text { Explicit } \\
\text { conflicts } & \text { between } \\
\text { managers } & \text { and } \\
\text { governance boards. }\end{array}$ \\
\hline PSR & $\begin{array}{l}\text { PSR } \\
\text { Not formalised vision } \\
\text { statement, but the } \\
\text { purpose of the firm is } \\
\text { shared at } 70 \% \\
\text { A highly embedded SR } \\
\text { is developed: they look } \\
\text { at the market, and at } \\
\text { the rivals, as ideas } \\
\text { source and they } \\
\text { translate them to the } \\
\text { product. }\end{array}$ & $\begin{array}{l}\text { PSR } \\
\text { Formalised vision statement. } \\
\text { The purpose of the firm is } \\
\text { now proactively shared by a } \\
\text { majority of the workers. } \\
\text { Proactive strategy is } \\
\text { launched. Besides, external } \\
\text { SR activities are developed } \\
\text { following a business } \\
\text { network proposals. }\end{array}$ & $\begin{array}{l}\text { Not PSR } \\
\text { Not formalised vision } \\
\text { statement. The purpose } \\
\text { of the firm is not } \\
\text { shared and SR is not } \\
\text { proactive. } \\
\text { SR is not specifically } \\
\text { developed. It is not a } \\
\text { key issue of the } \\
\text { cooperative. }\end{array}$ \\
\hline
\end{tabular}

Source: Own elaboration

\section{DISCUSSION AND CONCLUSIONS}

The cooperative principles are expected to be the foundations of PSR in cooperatives. Therefore, cooperatives are supposed to be responsible towards their members and the society in general and, at the same time, economically viable (Mozas et al., 2010). However, this responsible behaviour can be hindered by a declining economy because economic crisis can deteriorate SR principles development at workers, managers and governance level. 
After the three cases analysis, we can see that the SR principles are more embedded and less deteriorated by economic downturn in case A, where identified problems are avoided and proactiveness is presented in the current behaviour of the organization, including SR. Similar situation happens in case $\mathrm{B}$, but the workers engagement and participation are based on the recently defined business project and the new organizational change. Finally, in case $\mathrm{C}$ the mentioned problems arise and internal conflict carries out that the SR principles not to be at the core criteria of decision taking. As a result, CEO was fired and the organization has a reactive attitude face to the economic situation.

In $\mathrm{A}$ and $\mathrm{B}$ cases economic pressures do not hinder cooperative principles and PSR is developed. A remarkable similarity is shared in both cooperatives: the relationship between Government Council and the CEO is aligned with the cooperatives' principles. In both cases, traditional social preserving institutions are substituted by the leader example and personality in direct contact with employees (case A), and by the external advisor that facilitates social issues application (case B). Therefore and focusing on cooperatives governance and management, two conditions have been identified in order to guarantee the PSR: the existence of a leader promoting shared cooperative principles embedded in the cooperative's activity and the government and management boards alignment in terms of cooperative mission and vision.

First, the presence of a leader supporting shared cooperative principles embedded in the cooperative's activity is considered, in the academic literature, one of the main relevant factors of SR is the set of values of the organization (Longenecker, Petty, Moore \& Palich, 2006; Preuss \& Perschke, 2010). In particular, the leader is a relevant figure in case of regeneration of the social engagement of cooperatives, because they maintain participation; reduce the knowledge power gaps between members; preserve collective interest above selfinterest (Sousa, Pattison \& Herman, 2012).

Second, to be a real glue of the organizational behaviour, this 'cooperative soul' has to be communicated, shared and interiorized by all members of the organization (Vargas \& Vaca, 2005), and it requires the management level (either the CEO or the management committee) and the Governing Council alignment around the cooperatives mission and vision to lead the organization to a sustainable and competitive position. In this sense, the asymmetric power of both teams generates negative effects and situations to avoid. On the one side, the lack of participation of the owners in decision-making processes (Boundy, 1981; 
Matheson \& Olson, 1994; McConvill \& Bagaric, 2004; Chizema, 2011) that can be due to not to have sufficient power or knowledge to influence corporate decisions and, on the other side, the abusive use of power by owners that inhibits CEO's decision-making power.

The three cases analysed confirm the relevance of the conditions. The cases A and B are two examples of PSR with a largely engaged organization around cooperative principles. The first case relies on an experienced leader. This leadership reaches a high level of consensus around cooperative principles among the workers. Although it is a classical case, other options are also possible. In case B, the alignment around cooperative principles is based in a participative leadership as there is not a CEO but the cooperative is managed by a group of team leaders. This collective board is leaded by a democratically selected president and a consultant group. The management and governance alignment around cooperatives' mission is high in case A and B. The third case, has not reach a consensus between the governance and the management board. In this case, SR is not at the centre of the cooperative's activity and it wanders. Consensus in case $\mathrm{C}$ is not reached due to the opposition between workers presented in the Governing Council and the CEO.

The contribution of the paper is relevant both to scholars and to practitioners. On the one hand and related with scholars, we first contribute to the literature by a preliminary exploration about how the economic crisis can deteriorate cooperative's SR; besides, by focusing in a set of conditions to develop PSR in economic crisis periods, we introduce the governance and management issues as drivers in this context; and, finally, showing heterogeneous SR in the cooperative context (Arcas and Briones, 2009). On the other hand, according with the practical contributions, the need to develop managerial and governance capabilities towards the sustainable and participative management that the cooperative principles application requires is proved. In this sense, management education has an important role enhancing these abilities and management techniques needed for development of PSR.

This article is a first and necessary step that attempts to analyse PSR in crisis periods in the cooperative context and establishes its theoretical basis, since most of the studies in the area have focused mainly in large firms or SMEs. However, further research on this subject is needed. Additional case studies are welcomed to improve the external validity of the study; the definition of the specific process to successfully develop PSR; the role of stakeholders, in particular the agents involved in governance, and the influence of different configurations of 
the stakeholders' information structures in PSR would be very interesting for future research initiatives. Besides, future contributions must address the development of a larger research that should be undertaken to generalise the arguments in different cooperative contexts.

\section{ACKNOWLEDGEMENTS}

Thanks are due to the cooperatives' leaders that have provided the required evidences for this paper, and we acknowledge financial support from the Basque Government Department of Education Language Policy and Culture.

\section{REFERENCES}

ADAMU, A. (2009) The effects of global financial crisis on Nigerian economy. (Working paper), Nasarawa State: Nasarawa State University, Keffi.

AIZENMAN, J., CHINNA, M.D., \& ITO, H. (2010) The financial crisis, rethinking of the global financial architecture, and the trilemma. (ADBI Working Paper Series). Retrieved November 24, 2010, from http://web.pdx.edu/ ito/ACI_adbi09162009.pdf

ARCAS, N., \& BRIONES, A.J. (2009) Responsabilidad social empresarial de las organizaciones de la economía social. Valoración de la misma en las empresas de la Región de Murcia. CIRIEC - España, Revista de Economía Pública, Social y Cooperativa, $\mathrm{N}^{\mathrm{o}} 65$, pp. 143-161.

AREVALO, J.A., \& ARAVIND, D. (2010) The impact of the crisis on corporate responsibility: the case of UN global compact participants in the USA. Corporate Governance: The International Journal of Business in Society, № 10, Vol. 4, pp. 406-420.

BARRERA, E. (2007) La empresa social y su responsabilidad social. Innovar. Revista de Ciencias Administrativas y Sociales, № 17, Vol. 30, pp. 59-75.

BEL, P., \& MARÍN, S. (2008) Criterios de eficiencia y buenas prácticas en los procesos de concentración de las organizaciones de participación. REVESCO. Revista de Estudios Cooperativos, $\mathrm{N}^{\circ}$ 95, pp. 9-43.

BELHOUARI, A., BUENDÍA, I., LAPOINTE, M.J., \& TREMBLAY, B. (2005) La responsabilidad social de las empresas: ¿un nuevo valor para las cooperativas?. CIRIEC España, Revista de la Economía Pública, Social y Cooperativa, № 53, pp. 191-208.

BENN, S., DUNPHY, D. \& GRIFFITHS, A. (2006) Enabling Change for Corporate Sustainability: An Integrated Perspective. Australasian Journal of Environmental Management, № 13, Vol. 3, pp. 156-165. 
BERRY, M.A. \& RONDINELLI, D. A. (1998) Proactive Corporate Environment Management: A New Industrial Revolution. Academy of Management Executive, $\mathrm{N}^{\mathrm{o}} 12$, Vol. 2, pp. 38-50.

BOUCHON , C., MIHCARD, B., PLASSE, A., \& PARANQUE, B (2012) Cooperatives et gouvernance: modernité ou archaïsme?, Annals of Public and Cooperative Economics, $\mathrm{N}^{\circ}$ 83, Vol. 3, pp. 317-335.

BOUNDY, C. (1981) Shareholder agreements - The key to positive management. Journal of General Management, № 6, Vol. 4, pp. 39-49.

CALDERON, B., \& CALDERON, M.J. (2012) Cómo afrontan la crisis las cooperativas en España: comparativa de trayectorias laborales a partir de la Muestra Contínua de Vidas Laborales. CIRIEC - España, Revista de la Economía Pública, Social y Cooperativa, № 76, pp. 5-26.

CARROLL, A. B. (1979) A Three-Dimensional Conceptual Model of Corporate Performance. Academy of Management Review, No 4, Vol. 1, pp. 497-505

CASTRO, M. (2006) Las empresas de economía social y la responsabilidad social corporativa. Papeles de Economía Española, No 108, pp. 92-104.

CEBALLO, A.I. (2005) Responsabilidad social: un valor añadido para las empresas, un criterio de discriminación positiva para los consumidores. CIRIEC - España, Revista de Economía Pública, Social y Cooperativa, № 53, pp. 65-77.

CHERUBIM, F., \& MOURA, D.R. (2012) The importance of cooperatives' corporate social responsibility to the loyalty of members. Journal of Rural Cooperation, № 40, Vol. 2, pp. 198-216.

CHIZEMA, A. (2011) The empowerment of shareholders: a conceptual perspective. Journal of General Management, No 36, Vol. 4, pp. 23-35.

COLLADO, J.L. (2006) La Responsabilidad social corporativa y las cooperativas: aspectos y formulaciones comunes. XI Jornadas de Investigadores de Economía Social y Cooperativa, Santiago de Compostela, España,

DU, S., BHATTACHARYA, C.B. \& SEN, S. (2007) Reaping Relational Rewards from Corporate Social Responsibility: The Role of Competitive Positioning. International Journal of Research in Marketing, № 24, Vol. 3, pp. 224-241.

DUCASSY, I. (2013) Does Corporate Social Responsibility Pay Off in Times of Crisis? An Alternate Perspective on the Relationship between Financial and Corporate Social Performance. Corporate Social Responsibility and Environmental Management, № 20 , pp.157-167. 
EISENHARDT, K.M. (1989) Building theories from case study research. The Academy of Management Review, № 14, Vol. 4, pp. 532-550.

EISENHARDT, K.M., \& MARTIN, J.A. (2000) Dynamic capabilities: What are they?. Strategic Management Journal, No 21, Vol. 10/11, pp. 1105-1121.

EUROPEAN COMMISSION. SME and cooperation, 2003/5. Luxemburg: Office for Official Publications of the European Communities.

EUROPEAN COMMISSION. Economic crisis in Europe: Causes, consequences and responses, 2009/7. Luxemburg: Office for Official Publications of the European Communities. DOI: 10.2765/84540.

FAMA, E.F. \& JENSEN, M. C. (1983) Separation of ownership and control. The Journal of Law \& Economics, № 26, Vol. 2, pp. 301-325.

FERNÁNDEZ-FEIJÓO, B. (2009) Crisis and corporate social responsibility: Threat or opportunity?, International Journal of Economic Sciences and Applied Research, № 2, Vol. 1, 36-50.

FOMBRUN, C., \& SHANLEY, M. (1990) What's in a name? Reputation building and corporate strategy. Academy of Management Journal, № 33, Vol. 2, pp. 233-258.

GIANNARAKIS, G., \& THEOTOKAS, I. (2011) The effect of financial crisis in corporate social responsibility performance. International Journal of Marketing Studies, $\mathrm{N}^{\mathrm{o}} 3$, Vol. 1, pp. 2-10.

GREENING, D.W., \& TURBAN, D.B. (2000) Corporate social performance as a competitive advantage in attracting a quality workforce. Business and Society, № 39, Vol. 3, pp. 254280.

GROZA, M.D., PRONSCHINSKE, M.R. \& WALKER, m. (2011) Perceived Organizational Motives and Consumer Responses to Proactive and Reactive CSR. Journal of Business Ethics (Online 24 March), pp. 1-14.

HART, S.L., \& AHUJA, G. (1996) Does it pay be green?: An empirical examination of the relationship between emission reduction and firm performance. Business Strategy and the Environment, $\mathrm{N}^{\mathrm{o}}$ 5, pp. 30-37.

HRISTACHE, D.A., PAICU, C.E., \& ISMAIL, N. (2013) Corporate social responsibility and organizational identity in post-crisis economy. Theoretical \& Applied Economics, $\mathrm{N}^{\circ} 18$, Vol. 1, pp. 113-120.

ITÇAINA, X. (2002) Catholicisme, économie identitaire et affinités electives: les coopératives basques comme groupements volontaires utopiques, Social Compass, $\mathrm{N}^{\mathrm{o}} 49$, Vol. 3, pp. 393-411. 
JENKINS, H. (2006). Small business champions for corporate responsibility. Journal of Business Ethics, No 67, Vol. 3, pp. 241-256.

KARAIBRAHIMOGLU, Y.Z. (2010) Corporate social responsibility in times of financial Crisis. African Journal of Business Managament, $\mathrm{N}^{\circ}$ 4, Vol. 4, pp. 382-389.

KLASSEN, R.D. \& WHYBARK, D.C. (1999) The Impact of Environmental Technologies on Manufacturing Performance. Academy of Management Journal, № 42, Vol. 6, pp. 599615

KOLK, A., \& PINKSE, J. (2006) Stakeholder mismanagement and corporate social responsibility crises. European Management Journal, No 24, Vol. 1, pp. $59-72$.

KRAUSS, A., RŪTELIONĖ, A., \& PILIGRIMIENĖ, Z. (2010) SME in search for feasible concepts for systematic social responsibility in times of crisis. Economics \& Management, No 15 , pp. 635-641.

LEPOUTRE, J., \& HEENE, A. (2006) Investigating the impact of firm size on small business social responsibility: a critical review. Journal of Business Ethics, № 67, Vol. 3, pp. 257273.

LIN, L., GENG, X, \& WHINSTON, A.B. (2005) A sender-receiver framework for knowledge transfer. MIS Quaterly, № 29, Vol. 2, pp. 197-219.

LONGENECKER, J.G., MCKINNEY, J.A., \& MOORE, C.W. (1989) Ethics in small business. Journal of Small Business Management, № 27, Vol. 1, pp. 27-31.

LONGENECKER, J.G., PETTY, J.W., MOORE, C.W., \& PALICH, L.E. (2006) Small business management, An entrepreneurial emphasis, Thomson South Western, London.

MANUBENS, M. (2009) Corporate social responsibility in an economic crisis: An opportunity for renewal. Global Business and Organizational Excellence, № 29, Vol. 1, pp. 50-60.

MARÍN, L., \& RUBIO, A. (2008) ¿Moda o factor competitivo? Un estudio empírico de responsabilidad social corporativa en Pyme. Tribuna de Economía - Revista ICE, № 842, pp. 177-194.

MATHESON, J., \& OLSON, B. (1994) Corporate cooperation, relationship management, and the trialogical imperative for corporate law. Minnesota Law Review, № 78, pp. 14431481.

MCCONVILL, J., \& BAGARIC, M. (2004) Towards mandatory shareholder committees in Australian companies. Melbourne University Law Review, № 28, Vol. 1, pp. 125-168. 
MIRAS, M. M., ESCOBAR, B. \& CARRASCO, A. (2014) Are Spanish Listed Firms Betting on CSR during the Crisis? Evidence from the Agency Problem. Business and Management Research, $\mathrm{N}^{\mathrm{o}}$ 3, Vol. 1, pp. 85-95.

MOZAS, A., PUENTES, R., \& BERNAL, E. (2010) La e-corporate social responsability en las sociedades cooperativas agrarias andaluzas. CIRIEC - España, Revista de Economía Pública, Social y Cooperativa, No 67, pp. 187-212.

MOSHMAN, D. (1998) Cognitive development beyond childhood. in Kuhn, D. and Siegler, R. (Ed.) Damon,W. (Series Ed.) Handbook of child psychology, Vol.2: Cognition, perception, and language, Wiley, New York, NY, pp. 947-978.

NJOROGE, J. (2009) Effects of the global financial crisis on corporate social responsibility in multinational companies in Kenya. Geneva: Ethical Information Analyst Intern, Covalence SA.

PALOMO, R.J., \& VALOR, C. (2004) El "activismo" de los socios como catalizador de la responsabilidad social de la empresa: aplicación a las organizaciones de participación. CIRIEC - España, Revista de Economía Pública, Social y Cooperativa, № 50, pp. 167190.

PEIXE, J. B., \& PROTIL, R.M. (2007) Avaliação da eficiência das cooperativas agroindustriais paranaenses: uma abordagem econômica e social utilizando DEA. Proceedings of the I Seminário sobre Cooperativismo e Desenvolvimento Paranaense, Toledo, 2007, (from http://www.sober.org.br/palestra/9/690.pdf)

PÉREZ, J., ESTEBAN, L., \& GARGALLO, A. (2009) Participación, gobierno democrático y resultados cooperativos: una perspectiva de RSE. CIRIEC - España, Revista de Economía Pública, Social y Cooperativa, No 65, pp. 163-190.

PREUSS, L., \& PERSCHKE, J. (2010) Slipstreaming the larger boats: Social responsibility in medium-sized businesses. Journal of Business Ethics, $\mathrm{N}^{\circ}$ 92, Vol. 4, pp. 531-551.

PUENTES, R., \& VELASCO, M.M. (2009) Importancia de las sociedades cooperativas como medio para contribuir al desarrollo económico, social y medioambiental, de forma sostenible y responsable. REVESCO. Revista de Estudios Cooperativos, No 99, pp. 104129.

RIZKALLAH, É., \& BUENDIA, I. (2011) Corporate Social Responsability in the financial sector: are financial cooperatives Reddy to the challenge. CIRIEC - España, Revista de Economía Pública, Social y Cooperativa, № 73, pp. 127-149. 
RUIZ, M., DE LOS RÍOS, A., \& TIRADO, P. (2009) La responsabilidad social y la crisis económica. ¿Responden las entidades financieras españolas a los grupos de interés?. CIRIEC - España, Revista de Economía Pública, Social y Cooperativa, № 65, pp. 33-58.

RUSSO, M.V., \& FOUTS, P.A. (1997) A resource-based perspective on corporate environmental performance and profitability, Academy of management Journal, $\mathrm{N}^{\mathrm{o}} 40$, Vol. 3, pp. 534-559.

SERVER, R.J., \& CAPÓ, J. (2009) La responsabilidad social empresarial en un contexto de crisis. Repercusión en las sociedades cooperativas. CIRIEC - España, Revista de Economía Pública, Social y Cooperativa, Nº5, pp. 7-31.

SERVER, R.J., \& VILLALONGA, I. (2007) Responsabilidad social en el cooperativismo de crédito. El Fondo de Educación y Promoción como indicador para su evaluación. Estudio Empírico para el caso español. Intercencia, № 32, Vol. 6, pp. 337- 384.

SHARMA, S. \& VREDENBURG, H. (1998) Proactive Corporate Environmental Strategy and the Development of Competitively Valuable Organizational Capabilities. Strategic Management Journal, № 19, Vol. 8, pp. 729-753.

SOUSA, J., PATTISON, D., \& HERMAN, R. (2012). Thematic exploration and looking forward, in Sousa, J., \& Herman, R. (ed.). A co-operative dilemma, Centre for the Study of Co-operatives, Saskatton, Canada, pp. 271-310.

TADDEI, J. C., \& DELÉCOLLE, T. (2012) The role of cooperatives and CSR: the case of the French agricultural sector. International Business Research, $\mathrm{N}^{\circ}$ 5, Vol. 7, pp. 73.

TAYLOR, J.B., \& WILLIAMS, J.C. (2009) A black swan in the money market. American Economic Journal, $\mathrm{N}^{\mathrm{o}}$ 1, Vol. 1, pp. 58-83.

TORUGSA, N.A., O’DONOHUE, W., \& HECKER, R. (2012) Capabilities, proactive CSR and financial performance in SMEs: Empirical evidence from an Australian manufacturing industry sector. Journal of Business Ethics, $\mathrm{N}^{\circ} 109$, pp. 483-500.

VAN DER VEGT, G.S., DE JONG, S.B., BUNDERSON, J.S., \& MOLLEMAN, E. (2010) Power asymmetry and learning in teams: The moderating role of performance feedback. Organization Science, № 21, Vol. 2, pp. 347-361.

VARGAS, A., \& VACA, R.M. (2005) Responsabilidad Social Corporativa y cooperativismo: Vínculos y potencialidades. CIRIEC - España, Revista de Economía Pública, Social y Cooperativa, $\mathrm{N}^{\mathrm{o}}$ 53, pp. 241-260.

VYAKARNAM, S., BAILEY, A., MYERS, A., \& BURNETT, D. (1997) Towards an understanding of ethical behaviour in small firms. Journal of Business Ethics, № 16, Vol. 15, pp. 1625-1636. 
WANOUS, J.P. (1992) Organizational entry: Recruitment, selection, orientation, and socialization of newcomers. New York: Adisson-Wesley.

WARTICK, S.L. \& COCHRAN, P.L. (1985) The Evaluation of the Corporate Social Performance Model. Academy of Management Review, No 10, Vol. 4, pp. 758-769.

WILLIAMSON, J.G. (1965). Regional inequality and the process of national development: a description of the patterns. Economic development and cultural change, $\mathrm{N}^{\mathrm{0}} 13$, Vol. 4, pp. $1-84$.

WILSON, L. (1975) 'What One Company Is Doing about Today's Demands on Business', in G. A. Steiner (ed), Changing Business-Society Interrelationships (Graduate School of Management, UCLA, Los Angeles)

WIM, N. (2009) The financial crisis of 2008 and the Developing Countries. (Working Paper) Helsinki: The World Institute for Development Economics Research, United Nations University.

YIN, R.K. (1989) Case study research: Design and methods. London: Sage Publications.

YIN, R.K. (1994) Case study fesearch. Design and methods. (2 ${ }^{\text {nd }}$ ed.) London: Applied Social Research Methods Series 5, Sage Publications. 